\title{
Analysis of Claims in Public Works Construction Contracts in India
}

\author{
*Amit Moza and Virendra Kumar Paul
}

Published online: 25 January 2019

To cite this article: Amit Moza and Virendra Kumar Paul (2018). Analysis of claims in public works construction contracts in India. Journal of Construction in Developing Countries, 23(2): 7-26. https://doi.org/10.21315/jcdc2018.23.2.2.

To link to this article: https://doi.org/10.21315/jcdc2018.23.2.2

\begin{abstract}
Majority of construction works are carried out through contracts and most of public works in India are modeled on General Conditions of Contract (GCC) formulated by Central Public Works Department (CPWD). Such Public Works Contracts have inherent limitations of being adapted on case to case and thus, are perceived to be rigid and prone to disputes. An attempt has been made to understand and evaluate the relationship between contract conditions and different claims that are usually encountered in construction disputes. An assessment has been done to determine the root cause of various claims with respect to contract conditions with a view of suggesting certain changes in GCC for effective contract management. Twenty two disputes in arbitration from CPWD have been considered and the claims subject to arbitration were studied and analysed. Classification and categorisation of claims was done and frequency of claims, quantum of amount claimed and amount awarded were determined for each type which was then related with the conditions of contract guiding them. Suggestions have been put forward on the basis of limited study as changes that can be made in GCC of CPWD, for avoiding the claims to arise in the first place.
\end{abstract}

Keywords: Claim, Construction, Contract, CPWD

\section{INTRODUCTION}

The construction industry in India is the second largest industry after agriculture (Indianconstructionindustry.com, 2007). Given the fact that strong infrastructure facilities form the backbone of a nation's economy, the performance of project execution has not been commensurate with increased focus on infrastructure development in India. As per a study conducted by McKinsey and Company (Gupta, Gupta and Netzer, 2009), on an average, projects in India across sectors suffer from time and cost over-runs to the tune of $20 \%$ to $25 \%$, with some sectors affected by more than $50 \%$. Frequent and long-drawn disputes between contractors and clients also slow down the progress of construction work. In India, as per the report, of the USD80 billion Gross Domestic Product (GDP) loss due to inefficient execution, USD50 billion is attributable to these time and cost over-runs, many of which are a result of disputes at some stage of the process.

Disputes are common and unavoidable in most construction projects due to a number of uncertainties that may occur. According to various researchers like Hellard (1987), Kumaraswamy (1997), Odeh and Battaineh (2002), Assaf and Al-Hejji (2006) and Yates and Epstein (2006), disputes generally arise because of varied contractual reasons like ambiguity in contract documents, poor communication, changes in scope and can also arise due to unforeseen circumstances. The

Department of Building Engineering and Management, School of Planning and Architecture, New Delhi, INDIA

*Corresponding author: amitmoza15@gmail.com 
disputes also have genesis in the way contractual issues evolve through claims (Mitkus and Mitkus, 2014). A simplistic definition of a claim is "a request, demand, or assertion of rights by a seller against a buyer, or vice versa, for consideration, compensation, or payment under the terms of a legally binding contract, such as for a disputed change" (Project Management Body of Knowledge [PMBOK], 2017). Claims might be made for loss and expense, extension of time, liquidated damages and might also due to a number of uncertainties in construction projects and so on. It is imperative that the contract sets out clearly what can constitute a claim and how it should be dealt with less the disputes would be inevitable. However, this is easier said than done. Putting together a contract document which will ensure that claims do not arise in the first place has been elusive so far despite huge literature and studies carried out on this subject. One of the primary reasons, cited by earlier researchers (lyer, Chaphalkar and Joshi, 2008) for this is that no matter how detailed a document is, it is still open to interpretation by different people who have varied interests in the project. Notwithstanding this, the conditions of contract play a significant role in escalating or arresting causes of disputes in a contract (Yates and Epstein, 2006). Thus in essence, the inability to deal with claims through contractual instruments can lead to disputes.

Contemporary construction projects bring in complexities in the form of design complications, new areas of development not known to project entities earlier which leads to more uncertainties and risks. Such projects then require organised planning, scheduling and complex legal and contractual documents (Rephan, 201 1). If the attention is not provided to such peculiarities, then the claims can arise which then lead to disputes if not settled timely.

It is being forecasted by PricewaterhouseCoopers (PWC) (2014) that India's construction sector is set to grow $7 \%-8 \%$ which will be further supplemented by relaxation in the Foreign Direct Investment (FDI) norms in construction. In such a scenario, construction practices shall be required to be more responsive because the stakes would not be limited to Indian jurisdiction only. Besides, this will bring in more complexity not only to the projects but also to the legal aspects associated with projects like contractual documentation and dispute resolution. It would be imperative to address these issues right in the beginning to avoid serious implications such as time delays, budget overruns and jeopardising project viability.

Majority of construction works are carried out through contracts. Most of the public infrastructure projects in India are carried out through central public agencies like Central Public Works Department (CPWD). Besides CPWD, other major departments carrying out project jobs are agencies like National Highway Authority of India (NHAI), Railways and Military Engineering Services (MES), etc. All other public projects, not being carried out directly by these big agencies, usually follow the standard contract conditions formulated by CPWD or MES. Federation Internationale des Ingenieurs Conseils (FIDIC) conditions were introduced in 1980s for some public works on the insistence of the funding agencies like World Bank and Asian Development Bank as it was felt that the prevailing contract conditions were not equitable. It was felt that the projects were likely to be delayed because of the fact that inequitable or ambiguous contract conditions lead to claims related to time, cost or other uncertainties as stated before which ultimately result in disputes.

Since majority of domestic infrastructure projects being carried out are still based on conditions of contract of CPWD, it is important to look into the conditions of the contract minutely to find out the reasons for occurrence of high number of claims in such contracts. 
In a scenario when construction industry is expected to have a boom in coming years, this paper attempts to examine the contract conditions more critically and look into nuances that often lead to claims which further lead to disputes. The paper aims at framing recommendations which may be incorporated as changes in contract conditions to avoid or minimise the disputes.

Construction processes and the conditions of contract are becoming more and more complex and consequently contribute to higher possibility of claims and disputes (Surawongsin, 2002). Discussions on engineering and construction claims and disputes are quite complicated and there are extensive resources and writings published and available in the public domain on this subject. In construction industry, due to its huge size and the fact that disruptions can cause heavy losses, it has been consistently raised as a serious concern by the industry members. Newey (1992) stated that prevention of dispute can be achieved through good and firm management such as prudent staffing policy, vigorous quality assurance plan, and realistic tender preparation and separating duties of design from contract administration.

There are researchers who have established different definitions of claims and disputes and then there are others who have researched on the causes of claims and disputes. For example, Mururu (1991) described dispute as a formation of a position to maintain in conflict while as Brown and Marriott (1999) suggested that dispute can be viewed as a class or kind of conflict that requires resolution. Hellard (1987) stressed upon the dimension of difference in objectives and stated that construction dispute is the opposition of interests, values or objectives. This view was further endorsed by Spittler and Jentzen (1992) who laid down that construction dispute was linked with difference in perspectives, interests, and agenda of human beings. All these views have been consistent on having conflict at the centre of everything. As people involved in a contract seek to maximise fulfilment of their own interests, or needs, by way of bargaining or negotiating through compromise, one party may yield to the other on that which is less important and when this happens, disputes are inevitable (Tillet, 1991).

While these studies were primarily focused on defining disputes, a different analysis of the studies reflects upon the types of disputes. This meant that the focus was on studying the matters that were subject to disputes in addition to defining what a dispute was. For example, Hewitt (1986) identified six types of construction disputes: change of scope, change conditions, delay, disruption, acceleration and termination. Similarly, Heath, Hills and Berry (1994) identified seven main types of construction dispute: contract terms, payments, variations, extensions of time, nomination, re-nomination and availability of information. Furthermore, researchers have also pointed out the underlying causes of the disputes. According to Diekmann, Girard and Abdul-Hadi (1994) people, process and product are the main sources of construction disputes. This was a rather generalised view on disputes which was furthered by Jones (1994) who laid down ten main sources of disputes: management, culture, communications, design, economics, tendering pressure, law, unrealistic expectations, contracts and workmanship.

There have been many other studies by Watts and Scrivener (1993), Conlin, Lanford and Kennedy (1996) and Kumaraswamy (1997) wherein researchers have identified various subject matters that become the basis of the disputes and have further provided their own classification on types of disputes. However, in all the studies carried out, contract conditions or contract terms has been cited as one of 
the key matters of disputes. It is one thing which remains common in almost all the studies carried out in the past.

There are studies carried out specifically with contract conditions as reference. For example, Semple, Hartman and Jergeas (1994) studied construction disputes and its various types with specific reference to the construction contract. Similarly, according to Yates (1998), variations, ambiguities in contract documents, inclement weather, late issue of design information/drawings, delayed possession of site, delay by other contractors employed by the client, postponement of part of the project were main types of construction dispute arising from the contract document. According to Yates and Epstein (2006), claims arise due to various reasons like improperly drafted contract documents, inaccurately prepared bids as well as inadequate contract administration on part of owners. Similar views were shared by Mitkus and Mitkus (2014), who stated that differences in interpretation of contract clauses create contractual problems leading to contractual claims.

In all above studies, contract documents has been cited to be one of the sources of construction disputes. Cheung and Yiu (2006) in their study identified three main ingredients of a construction dispute namely contract provisions, triggering event and conflict. They called it the "dispute triangle" model. According to them, these three ingredients have to be present in order for a dispute to arise. Sykes (1996) identified that construction disputes originate from two main interrelated sources: construction contracts and unpredictable events. Construction projects are more susceptible to uncertainties and therefore face a high amount of risk. In a bid to balance these risks through framing of contract conditions, one usually ends up providing a breeding ground for disputes. This may be because of failure to address sources of the uncertainties and instead try to plug them by contract administration. As a result, a contract document comes into force which is not only perceived unjust with risk loaded to only one side but also has contradictory provisions which were originally meant to deal with the uncertainties.

The GCC of CPWD is the predominant contractual framework for construction in India. Unfortunately, it has not been adequately researched to establish its efficacy in terms of elimination of disputes through effective claim management. Over the years the GCC structure has hardly undergone reforms due to such research, considering issues coming out of literature review above. More recently the GCC format has undergone improvements due to influence of international contract documents (verbatim) and need to align with interest of international funding agencies such as World Bank and Asian Development Bank (ADB).

This research study aims at analysing the claims usually encountered in these contract works with a view of assessing whether any underlying conditions of contract were responsible for the disputes. The study is founded on the hypothesis that a direct relationship exists between the contract conditions and claim prevention. Therefore, the research seeks to establish this relationship and determine if types of claims can be analysed in relation to contract conditions with an aim to affect claim prevention through proposed improvements in general conditions of contract.

\section{RESEARCH METHODOLOGY}

Twenty-two real life disputes in arbitration were obtained from two different arbitrators for study. The arbitrators chosen were former employees of CPWD itself who had handled many of the department's arbitrations and they were requested 
to provide some of their cases for study after explaining the purpose and objectives of the study. To maintain the homogeneity of the data and various parameters, the disputes in arbitration were taken from CPWD only which are governed by the GCC of CPWD. To maintain the confidentiality, each dispute in arbitration has been assigned a case number and a log sheet was made in which details of each case were recorded for reference and record. The paper, henceforth, shall address each dispute as a "case" without divulging either the name of the arbitrator or the details of the dispute in arbitration. Documents pertaining to statement of claims and counterclaims, rejoinders and award were obtained for each case for analysis.

The claims submitted for arbitration were studied and analysed for their repetitiveness and genuineness to ascertain if there was a correlation between occurrence of a claim and associated contract conditions. Stepwise methodology that was used in conducting the study is discussed in following section of this article.

\section{Classification and Categorisation of Claims}

The first step in analysing the claims that were subjected to arbitration is to carry out the categorisation of claims. For this purpose, the framework of claim analysis which was put forward in an earlier study (Saurabh, 2001) has been used. According to this study, claims are grouped under four major categories of "time related", "cost related", "quality related" and "miscellaneous". What justifies the use of this framework is that the categorisation allows one to see the claims in the context of three major determinants of project success, viz. time, cost and quality. Additionally, further subcategorisation of claims in it allows one to link them with specific contract conditions as explained in following paragraphs. The summary of classification of claims is presented in Table 1.

Table 1. Classification of Claims

\begin{tabular}{ll}
\hline Time & 1. T1: Compensation for delay in work by contractor \\
Related (T) & 2. T2: Delay in work due to details, approvals not timely provided \\
& 3. T3: Suspension of work by client (rescission) \\
Cost & 1. C1: Related to payments of Running Account (RA) bills/refunds \\
Related (C) & 2. C2: Related to payments other than RA bills \\
& 3. C3: Escalation of rates \\
& 4. C4: Deviation in quantities/specifications \\
& 5. C5: Job carried out at risk and cost \\
& 6. C6: Related to deduction of penalties/recoveries \\
Quality & 7. C7: Additional items \\
Related (Q) & 1. Q1: Difference in interpretation of Bill of Quantities (BOQ) \\
Miscellaneous & 2. Q2: Work not conforming to specifications \\
(M) & 1. M1: General damages/loss incurred due to contractors negligence \\
& 2. M2: General damages/loss incurred due to clients negligence \\
& 3. M3: Cost of arbitration \\
& 4. M4: Claims pertaining to interest due to delayed payments
\end{tabular}


The details of each subcategory are as follows:

1. T1 (Cost: Delay by contractor): Claims pertaining to compensation for delay in work by contractor; these are governed by Clause 2 of CPWD GCC which deals with compensation for delay and include claims put up by client for losses incurred due to delay in work by the contractor. These claims include liquidated damages, loss of profit due to delay in work, etc.

2. T2 (Cost: Delay by client): Claims related to delay in work due to necessary details, materials, etc. not provided by client to contractor in time and pertain to losses suffered by contractor due to idling of staff, plant and machinery on site, etc.

3. T3 (Cancellation of contract): These claims are pertaining to suspension of work before scheduled time. They are covered by Clause 3 (when contract can be determined) and Clause 14 (Carrying out Part Work at Risk and Cost of Contractor) of CPWD GCC and arise due to cancellation of contract by the client before completion on various grounds, termed illegal by contractor.

4. Cl (Related to payment of bills): These claims are pertaining to payment of Running Account (RA) bills and are governed by Clause 7 (Payment on Intermediate Certificate to be Regarded as Advances) and Clause 9 (Payment of Final Bill) of GCC. Claims coming up due to delayed payment, non-payment or part payment of running account bills to the contractor and even those addressing the recovery of rebate deducted from the bills in spite of certain condition not being fulfilled by the client are all included in this category.

5. C2 (Related to payment of deposits, etc.): These are claims related to payments other than RA bills and are covered by Clause 10B (Secured Advance on Nonperishable Materials) and Clause 45 (Release of Security Deposit after Labour Clearance) of CPWD GCC. These include claims pertaining to recovery of advances, rebates, recoveries against security deposit, charges for usage of services of client, etc.

6. C3 (Claims related to escalation of rates): Claims addressing the non-payment or part payment to the contractor or recovery of overpayment by the client on the pretext of escalations in rates as addressed in the Clause 10C (which deals with payment on account of increase in process/wages due to statutory orders) and 10CC (deals with payment due to increase/decrease in prices/ wages after receipt of tender for works) of the CPWD GCC are included in this category. These claims arise due to escalation in prices of various materials beyond a specified period as mentioned in contract that contribute to an increase in the rates of different items of contract.

7. C4 (Related to change in quantities): These are the claims related to deviation in quantities/specifications and are covered by Clause 12 (Deviation/Variation Extent and Pricing) of GCC. Claims for payment of works for deviated item quantities are a part of this category. Contractor claiming amount, which he deems due for extra work done in terms of extra legitimate quantity or any necessary changes in specifications from what was agreed in the contract, either on his own will or as per project manager's (PM)/client's instructions, is under this category. 
8. C5 (Claims pertaining to risk and cost): These claims arise when a contract is rescinded by the client midway and balance of the work is done by a third party at the risk and the cost of the original contractor who claims this levy as illegitimate.

9. C6 (Claims related to deduction of penalties/recoveries): These claims arise for or against penal recoveries for materials used by contractor, pilferage, overpayments made and deducted and other deductions and rebates.

10. C7 (Extra items): These claims pertain to additional items/work (Clause 12 of GCC). Claims which arise due to differences in opinion about the rates of new items or rates of the items with changed specifications as well as cost of works in dispute, which were not originally a part of the agreement between the two parties and were executed by the contractor as per client's/PM's instructions.

11. Q1 (Item description): Claims due to difference in interpretation of BOQ. This category includes claims for arising payments due to difference in interpretation/ opinion about an item of work, which may be attributed to ambiguous item definition or item not defined at all.

12. Q2 (Specifications not met): These claims are related to work not conforming to specifications, drawings, orders, etc. and are dealt by Clause 11 (Work to be Executed in Accordance with Specifications, Drawings, Orders, etc.), Clause 16 (Action in Case Work Not Done as Per Specifications) and Clause 24 of CPWD GCC. In such claims, the contractor demands for payments held back by the client/PM because the work is considered substandard, which as per the contractor, is an unjust accusation.

13. M1 (Damages: Contractor's fault): General damage/loss incurred due to contractor's negligence/fault. Claims demanding recovery of expenses or losses incurred by the client by any negligence or fault by the contractor not covered in any of the categories discussed above fall in this category.

14. M2 (Damages: Client's fault): General damage/loss incurred due to owners negligence/fault. Claims demanding recovery of expenses or losses incurred by the contractor's firm due to any reason other than those mentioned in previous categories shall be constituted in this category.

15. M3 (Cost of arbitration): Cost of arbitration proceedings. Claims falling in this category are on the account of expenses incurred in conducting arbitration proceedings and include fees to the arbitrators, expense on travel (if sought), expenses in arranging for place of hearing or any other such expense associated with arranging arbitration proceedings.

16. M4 (Interest claims): Claims pertaining to interests due on delayed payments. The interests claimed by either of the parties due to delay in payments on account, claimed or pending to be paid shall also be associated with this category.

\section{Claim Data Sheets}

Claim data sheets have been prepared for each dispute in arbitration, which involved tabulating claims and counterclaims in each case, categorising them as per above-mentioned categorisation, and capturing amount claimed and amount awarded against each claim. A part of a typical data sheet is presented in Figure 1. 
Data Sheet Case No. 22

\begin{tabular}{cccccc}
\hline \multicolumn{7}{c}{ Case: Hora Brothers (Claimant) vs UOI (Respondent) } \\
\hline $\begin{array}{c}\text { Claim/ } \\
\text { C. Claim }\end{array}$ & S/No. & \multicolumn{1}{c}{ Details of Claim } & Category & $\begin{array}{c}\text { Amount } \\
\text { Claimed }\end{array}$ & $\begin{array}{c}\text { Amount } \\
\text { Awarded }\end{array}$ \\
\hline C & 1 & $\begin{array}{l}\text { On account of short payment in RA } \\
\text { Bill due to withholding for test, etc. } \\
\text { On account of short payment in RA } \\
\text { Bill due to short measurements in } \\
\text { agreement items. }\end{array}$ & Q1 & ₹ 19,170 & ₹ 11,016 \\
\hline
\end{tabular}

Figure 1. Sample Case Data Sheet

\section{Consolidated Claim Data Sheet}

The data from claim data sheets for all 22 cases are then collated and arranged as per subcategory of claims. Such a consolidated claim sheet for all the cases with details as mentioned is presented in Table 2.

While the number of claims in a particular sub-category indicates the repetitiveness of the claims, the ratio of amount awarded to amount claimed indicates how legitimate or genuine the claims under the categories are. The above consolidation of data also allows one to rank the above identified "causes of claims" in increasing/decreasing order of sensitivity to a construction process.

\section{KEY FINDINGS}

The data in Table 2 has been summarised in Figure 2 from which it can be observed that, against average claim value of INR25.63 Lakh raised by claimant in a case, only INR7.46 Lakh, which is approximately $26 \%$, has been awarded. This situation indicates that majority of the disputes or claims that are put up for arbitration do not stand the test of law and are found out not to be genuine or legitimate as the amount awarded is very low compared to amount claimed. Furthermore, out of a total average amount of INR29.47 Lakh claimed in a case, only INR3.8 Lakh is the amount claimed by the respondent which in this case is the organisation framing the contract conditions. This suggests that the party which is not involved in framing the conditions of contract is, most of the times, the aggrieved one thereby indicating that the contact conditions are apparently loaded in the favour of the client who frames them.

\section{ANALYSIS}

The findings from the case studies are analysed under three categorisations: categorisation by number of claims to find out the repetitiveness of claims, categorisation by the amount claimed under each category and finally categorisation by the percentage of amount awarded against amount claimed in each category. This categorisation has been sought in order to find out which type of claims arise more often in disputes so that causes leading to them can be established and consequently remedial actions proposed. Similarly by categorising 


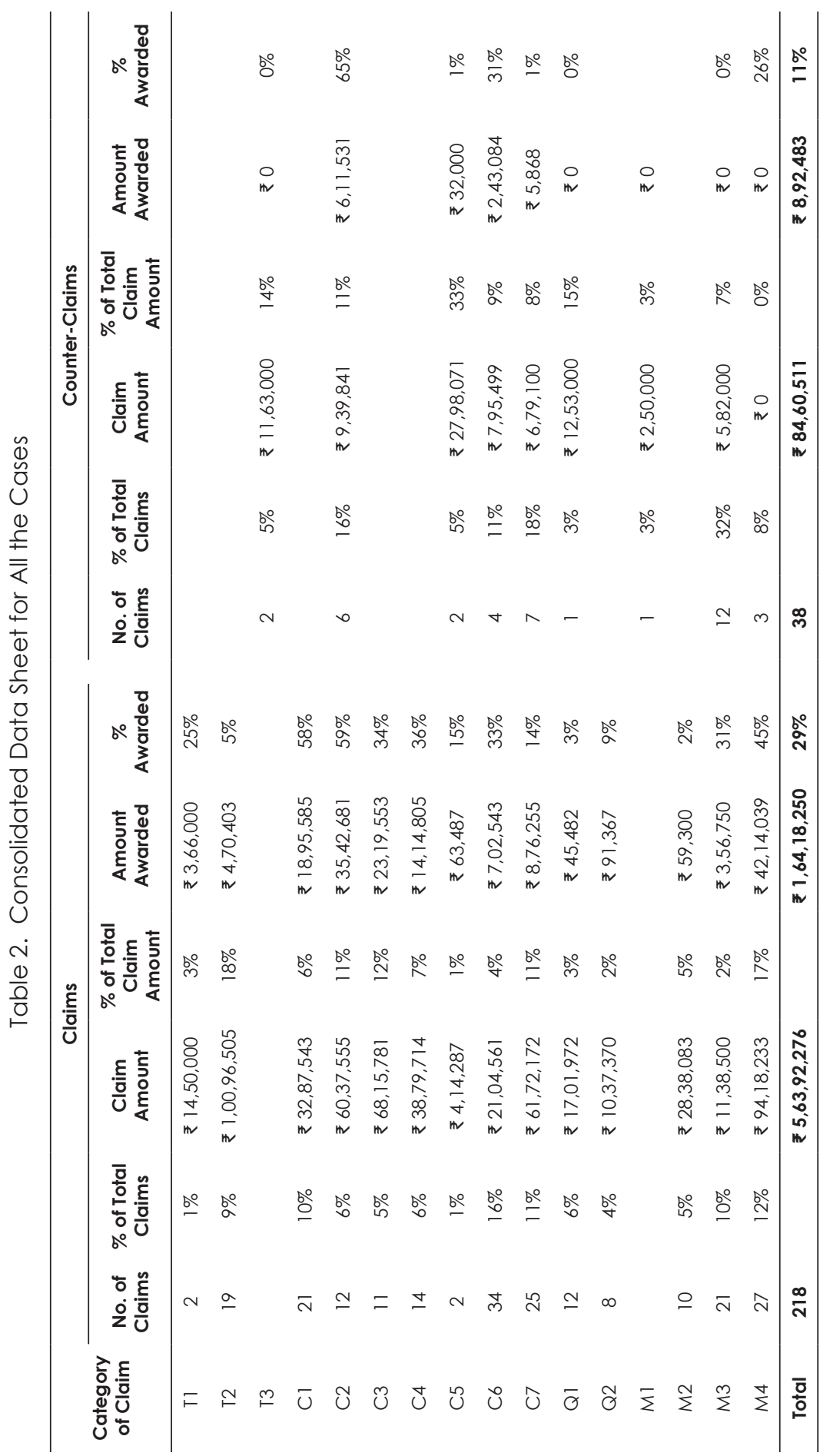


claims by the amount claimed enables one to establish claims which involve high amounts and thereby need to be tackled in the beginning itself to avoid high risk in case such claims are awarded. Categorisation by percentage amount awarded against amount claimed brings out the genuineness of the claims thereby suggesting the type of claims which do not merit much attention. The detailed analysis is explained in following sections.

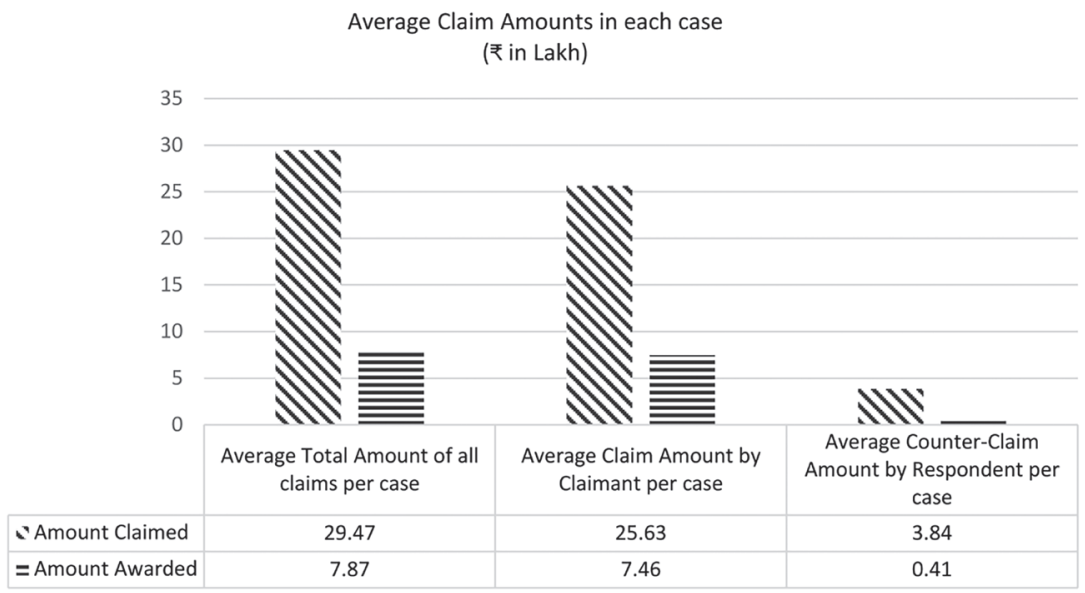

Figure 2. Consolidated Analysis of Claims

\section{Category with Maximum Claims}

From the available data in Table 2, a Pareto Chart has been made for total number of claims as a variable and is presented as Figure 3.

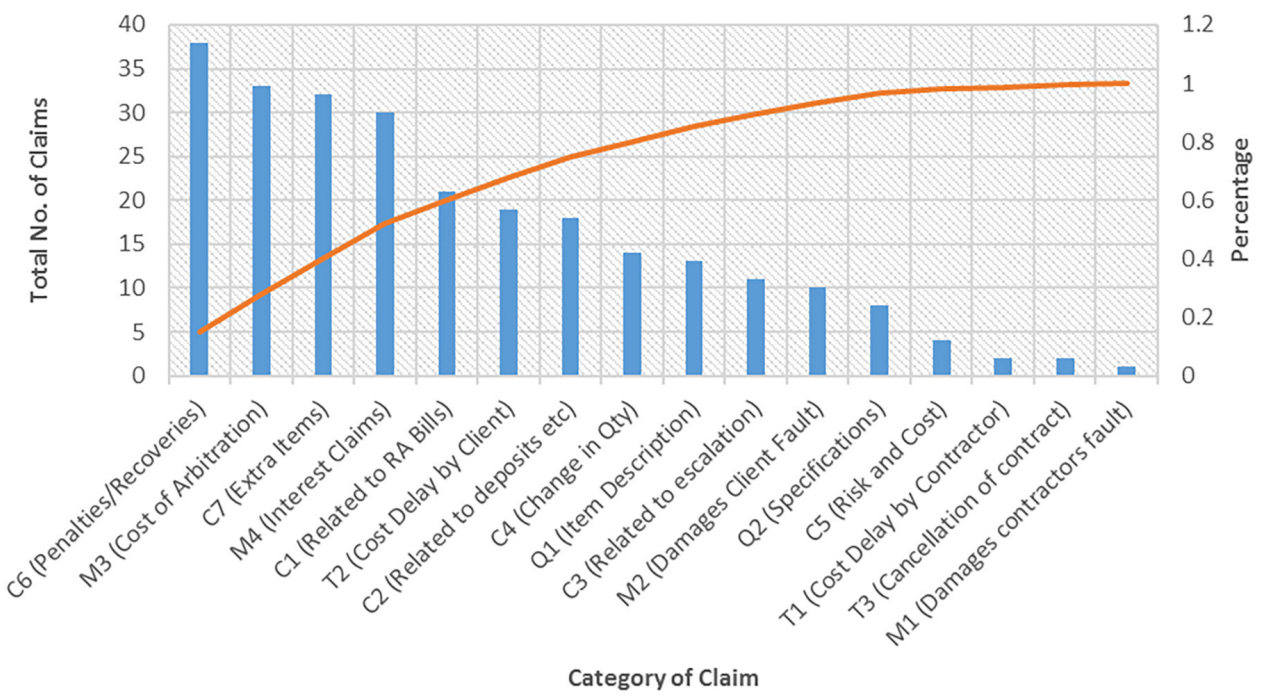

Figure 3. Claim Categories Sorted as per Number of Claims 
From the figure, it can be observed that maximum claims have been made under category C6 (38 out of 256) which are the claims related to deduction of penalties/recoveries, etc. This means that almost $16 \%$ of the claims subject to arbitration lie in this category.

It is closely followed by category M3, M4 and C7. M3 and M4 category of claims are the miscellaneous category claims and include costs spent on arbitration and interest costs respectively which are the categories that are of not much interest to this paper as they would inevitably crop-up once a dispute on other claims has already arisen. Category C7 includes claims raised for additional items of work carried out by contractor and has 30 claims under it for the cases under consideration which is almost $11 \%$ of the total claims. Together these four categories account for more than $50 \%$ of the total claims under arbitration.

\section{Category with maximum amount claimed}

Pareto Chart showing the amount claimed under each category is presented as Figure 4.

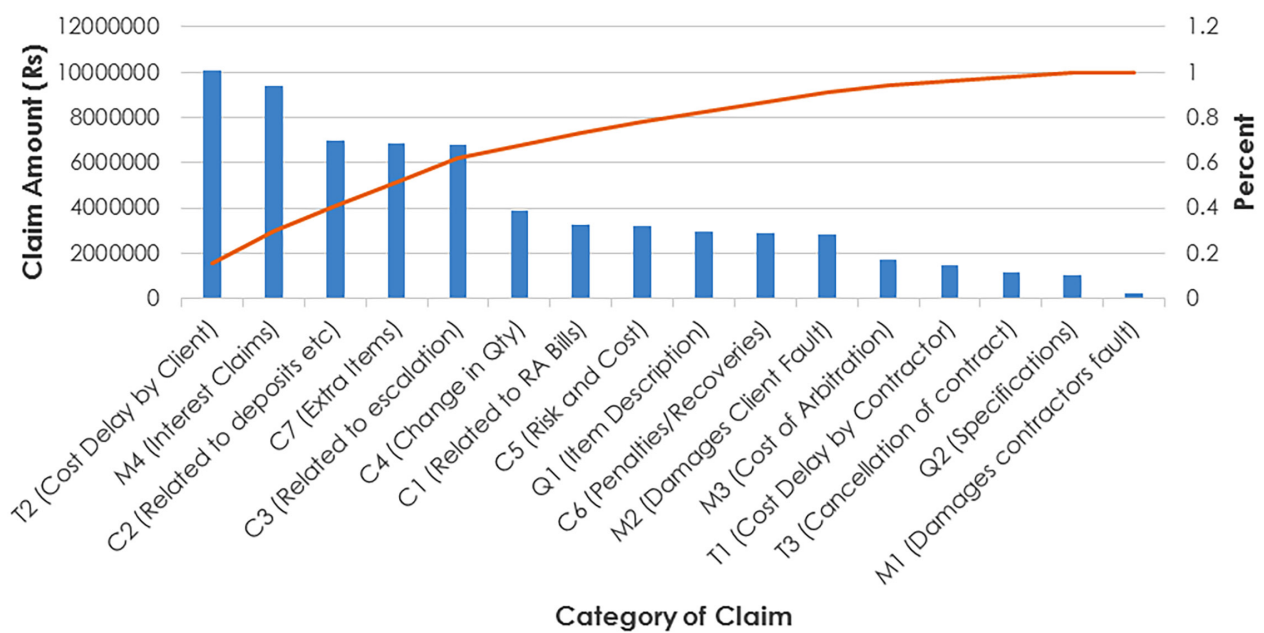

Figure 4. Claim Categories Sorted as per Amount Claimed

From the figure, it can be observed that maximum amount has been claimed under Category T2 (INR100 Lakhs out of INR648 Lakhs) which is $16 \%$ of the total amount claimed. The Category T2 consists of claims pertaining to delay in work due to client and includes losses suffered by contractor due to idling of staff, plant and machinery on site.

It is worthwhile to note that the total number of claims under this category constitute only $7 \%$ of the total number of claims. Since these claims pertain to projected losses, claimants usually exaggerate these claims which often are subject to revisions while being awarded.

The next highest category in terms of claimed amount is M4 with INR94 lakhs as amount claimed forming around $15 \%$ of the total claimed amount. This is understandable because every case more or less will have this claim at the end. 
Category C2, C7 and C3 and the next three categories with more or less similar claim amount close to INR68 Lakhs. It can be seen from the chart above that all five categories put together constitute more than $60 \%$ of the total amount claimed. Category C7 also has third largest number of claims compared to other four categories.

The least amount has been claimed in category MI (damages claimed by department on account of fault of contractor) with only INR2.54 Lakhs forming less than $0.5 \%$ of the total amount claimed.

\section{Category with maximum percentage amount awarded}

Pareto Chart displaying the amount awarded against each category is shown in Figure 5.

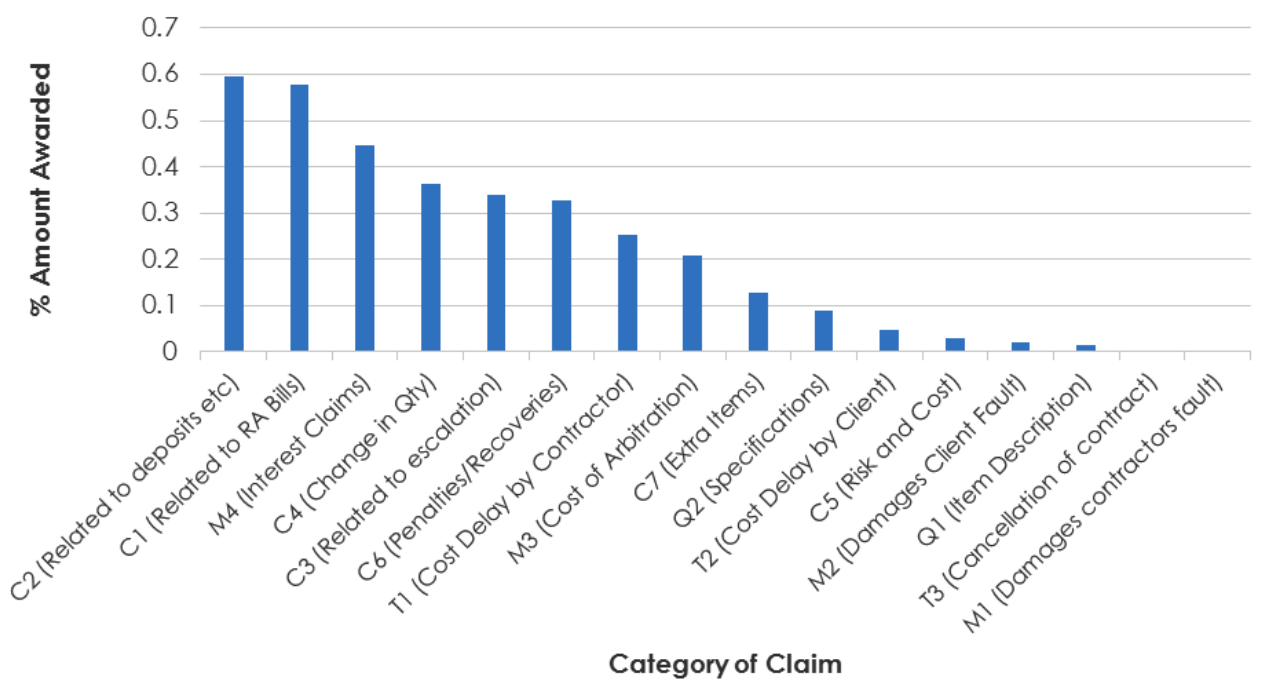

Figure 5. Claim Categories Sorted as per Amount Awarded

From the figure, it can be observed that Category C2 ranks highest with maximum amount awarded at close to $60 \%$ of the claimed amount followed by claims under Category $\mathrm{C} 1$ with $58 \%$ of the amount claimed being awarded even though C2 ranks as third and C1 ranks as 7th category under "Amount Claimed". This indicates that though the number as well as the value of claims under Category $\mathrm{C} 1$ and $\mathrm{C} 2$ are lower, the amounts awarded are highest thereby indicating the genuineness of the claims being raised under these two categories. These two categories of claims are the most successful claims.

On the other hand, Category T2 has the highest amount claimed while as Categories C6, M3 and C7 being top three categories in terms of number of claims have been awarded relatively lower amounts. Categories $M 1$ and T3 have not been awarded any amount. This situation indicates that the claims under these categories are fake claims and also that the amounts claimed under these categories are scaled up unrealistically. 
Category M4 ranks third highest with close to $45 \%$ of the amount claimed being awarded and constitutes close to $25 \%$ of the total amount awarded in all categories. Since this amount is also dependent upon the time for which interest in awarded by the arbitrator, the delay in arbitration proceedings itself can result in a higher amount in this category despite the fact that less than $26 \%$ claims were awarded in the first place.

Based on above analysis, the claims were ranked under above three categories and top five ranked claims were taken up for further analysis with an aim of suggesting some measures that might assist in minimising such claims. Table 3 presents the summary of these top five ranked claims in each category.

Table 3. Summary of Top Five Claims in Each Category

\begin{tabular}{|c|c|c|c|c|}
\hline \multirow[b]{2}{*}{ Category } & \multicolumn{3}{|c|}{ Ranking } & \multirow[b]{2}{*}{ Remarks } \\
\hline & $\begin{array}{l}\text { No. of } \\
\text { Claims }\end{array}$ & $\begin{array}{l}\text { Amount } \\
\text { Claimed }\end{array}$ & $\begin{array}{c}\text { \% Amount } \\
\text { Awarded }\end{array}$ & \\
\hline $\mathrm{T} 2$ & 6 & 1 & 11 & $\begin{array}{l}\text { 1. Delay in work due to client } \\
\text { 2. Ranks first in total amount claimed ( } 16 \% \text { ) } \\
\text { 3. Percentage amount awarded only } 4 \% \\
\text { 4. Amount awarded as } \% \text { of total amount } \\
\text { awarded only } 2 \% \text {. Low success rate. Not } \\
\text { genuine. }\end{array}$ \\
\hline $\mathrm{Cl}$ & 5 & 7 & 2 & $\begin{array}{l}\text { 1. Pertains to payment of RA bills/Final Bill } \\
\text { 2. Moderate number of claims ( } 8 \% \text { of total) } \\
\text { 3. Claimed amount only } 5 \% \text { of total claims } \\
\text { 4. Second most successful claim. } 58 \% \\
\text { awarded. Need intervention. }\end{array}$ \\
\hline $\mathrm{C} 2$ & 7 & 3 & 1 & $\begin{array}{l}\text { 1. Pertain to recovery of advances } \\
\text { 2. Moderate number of claims ( } 18 \text { out of } 256 \text { ) } \\
\text { 3. Accounts for } 11 \% \text { of total amount claimed } \\
\text { 4. Most successful claims. } 60 \% \text { of claimed } \\
\text { amount awarded }\end{array}$ \\
\hline C3 & 10 & 5 & 5 & $\begin{array}{l}\text { 1. Low number of claims: only } 4 \% \text { of total } \\
\text { 2. Moderate amount claimed at } 11 \% \text { of the } \\
\text { total claims } \\
\text { 3. } 35 \% \text { of the claimed amount awarded } \\
\text { 4. Reasonably successful claim }\end{array}$ \\
\hline $\mathrm{C} 4$ & 8 & 6 & 4 & $\begin{array}{l}\text { 1. Claims related to deviation in quantities/ } \\
\text { specifications } \\
\text { 2. Low number of claims ( } 5 \% \text { of total) } \\
\text { 3. } 36 \% \text { of the claimed amount awarded } \\
\text { 4. Reasonably successful claim }\end{array}$ \\
\hline C6 & 1 & 10 & 6 & $\begin{array}{l}\text { 1. Comprises claims that arise due to alleged } \\
\text { recovery of materials and other deductions } \\
\text { 2. Maximum number of claims ( } 15 \%) \\
\text { 3. Amount claimed only } 4 \% \\
\text { 4. Ranked } 6 \text { th in } \% \text { amount awarded }(33 \%)\end{array}$ \\
\hline
\end{tabular}


Table 3. (continued)

\begin{tabular}{|c|c|c|c|c|}
\hline \multirow[b]{2}{*}{ Category } & \multicolumn{3}{|c|}{ Ranking } & \multirow[b]{2}{*}{ Remarks } \\
\hline & $\begin{array}{l}\text { No. of } \\
\text { Claims }\end{array}$ & $\begin{array}{l}\text { Amount } \\
\text { Claimed }\end{array}$ & $\begin{array}{l}\text { \% Amount } \\
\text { Awarded }\end{array}$ & \\
\hline C7 & 3 & 4 & 9 & $\begin{array}{l}\text { 1. Claims pertain to extra items/work } \\
\text { 2. High number of claims ( } 15 \% \text { of the total } \\
\text { number) } \\
\text { 3. Moderate amount claimed at } 11 \% \text { of the } \\
\text { total } \\
\text { 4. Only } 13 \% \text { of amount claimed awarded } \\
\text { 5. Awarded amount forms only } 5 \% \text { of total } \\
\text { amount awarded }\end{array}$ \\
\hline M3 & 2 & 12 & 8 & $\begin{array}{l}\text { 1. Pertains to cost of arbitration } \\
\text { 2. Second highest number of claims with only } \\
\text { moderate success rate } \\
\text { 3. Low amount claimed }\end{array}$ \\
\hline M4 & 4 & 2 & 3 & $\begin{array}{l}\text { 1. Pertains to interest on amounts claimed } \\
\text { 2. High rankings in all three parameters }\end{array}$ \\
\hline
\end{tabular}

\section{DISCUSSION AND INFERENCES}

From Table 3, it can be observed that claims under Category T2 ranks first in amount claimed and accounts for $16 \%$ of the total amount claimed in all the cases which is the highest amount claimed in any category. However, percentage amount awarded against this category is only $4.6 \%$. Also the amount awarded as a percentage of total amount awarded is less than $2 \%$. Thus, it can be construed that most of the claims in this section are not genuine and are more of after-thoughts. Since the amount awarded is also less, these claims are not of much importance but nevertheless must be avoided to avoid the delay caused by frivolous claims in overall dispute resolution process. Same is the case with Category C7 where claims in this category are found to be more in number but at the same time not very legitimate and seem to be arising mainly due to difference in opinions on fixing rates of extra items and mode of calculations of the rates of these items. Many claims have been rejected by the arbitrators on these lines only or upheld partially by revising the method of calculations.

Similarly for Category $\mathrm{Cl}$, related to payment of running account and final bills, though the number of claims and amount claimed is only moderate, the amount awarded is $58 \%$ of the claimed amount and hence are genuine and reflective of the problems in contract execution. Same is the case with Category C2, C3 and C4 where the number of claims is low to moderate, but amount claimed and awarded is significant (within top five ranks) as compared to other categories. Category C6 is found to cause the maximum number of claims forming $15 \%$ of the total claims lodged with arbitrator. Though the amount claimed is not very high, almost $33 \%$ of the claimed amount under this category has been awarded. 


\section{RECOMMENDATIONS FOR CLAIM MANAGEMENT}

The analysis of claims carried out above not only provides the data on the most number of similar claims but also on how much was claimed under each category and more importantly how much was awarded against each claim to provide an idea of what constituted successful claims and which were frivolous. The outcome of this analysis made it possible to summarise the most important claims which, more or less accounted for a majority of issues that resulted in dispute. This analysis, when viewed along with the categorisation of claims carried out at the beginning of the study, enables one to relate the nature of a claim with the contract condition governing it thereby enabling one to notice the effect of such a condition on initiation of claims. The analysis shows that claim prevention to an extent can be achieved by managing contract conditions effectively. Following recommendations are proposed which might assist in reducing the chances of these issues cropping up in the first place and thereby help in reducing avoidable disputes.

\section{Recommendations for Category $\mathrm{C} 1$}

This category pertains to claims related to payment of running account and final bills and are one of the most successful claims in the process as almost $58 \%$ of the claimed amount in this category is awarded. This means that these claims are genuine and arise due to improper execution of the contract. Some of the recommendations are:

1. Withholding payments can result in financial hardships to the contractor which in turn leads to work disruption which leads to delay and delay leads to further deductions in the form of compensation and levies. This is thus, a vicious cycle which if set into motion will go perpetually until dispute is resolved by arbitration or courts. Hence every effort must be made to release RA Bills within time stipulated in contract.

In case of final bills, in case some things are pending, only a reasonable amount must be held back and remaining amount, say $90 \%$, must be released.

2. Just as delay on account of work entails the department to deduct compensation from the contractor, delayed payment too shall attract interest at rates which must be in line with market realities or as decided in the agreement itself. The Clauses in CPWD GCC concerned with payment of RA Bills (Clause 7 and 9) may be modified suitably to account for this. Having such a clause will not only be reassuring for the contractor and give him/her a sense of impartiality; it will also bring in a sense of urgency in the departmental staff in releasing the legitimate payments timely.

3. In most of the agreements studied, contractors have offered rebates only if RA bills are paid within stipulated time and it is one of the prominent causes of claims because when even one payment gets delayed, the contractor claims refund of entire rebate offered. This situation points to a lacuna in the wording of the clauses related to payment of bills. The relevant clause must be suitably modified to include different scenarios under which the rebate offered shall operate. This way contractor will know in advance the mechanism of how his offered rebate shall be handled which in turn will reduce the number of claims substantially. 
4. Similarly, reasons for delayed RA bills also seem to be stemming from a delay in verifying measurements. Though Clause 6 (Measurement of Work Done) and 6A (Requirement of Computerised Measurement Book) of GCC do talk about notice of seven days to be given to Engineer-in-Charge (EIC) for checking measurements, there is no mention of recourse to contractor in case it is not done as per GCC. Therefore, suitable modification to Clause 6 and 6A may be made to incorporate such recourse. In such a case the bill may be paid to the contractor and considered as advance against the final bill which shall be subject to verification.

\section{Recommendations for Category C2}

This category deals with claims pertaining to payment of recovery of advances such as mobilisation advance, plant and machinery advance, secured advances and even interest on advances. Issues related to security deposit too are clubbed in here. This claim category consists of most successful claims in all the cases studied. It must be kept in mind that if the quantum of claim value is reduced, dispute resolution may not be required at all because for lower claim value, neither of the parties may wish to press for it because the cost benefit analysis might not permit it. Thus, to first attack and address issues related to these successful claims would be an ideal thing to do. Following are the recommendations:

1. Interests and recovery of advances are often prone to disputes. If an interest free advance can be provided to the contractor in suitable instalments ensuring that the previous instalment is appropriately utilised in the related works on site, the claims can be reduced.

2. It has been observed that a number of claims are made by contractor on the pretext of release of security deposits. The contract conditions should explicitly state all such conditions under which only the security deposit can be held by the EIC. Also, clients are often found to have not intimated the contractor through appropriate show cause notices before withholding such amounts although the contract conditions provide it.

\section{Recommendations for Category C3}

This category of claims is related to escalation of rates during contract execution. From analysis, it is clear that the claim amount under this category is substantial with a fair success rate. This issue has been fairly dealt within the general conditions of contract of CPWD under Clause 10 and 10CC and the main issue seems to be the administrative procedures. However, following approaches are recommended:

1. Most issues in the cases studied pertain to escalation on works executed after extension of time period was given by the client. Therefore, the contract conditions must be suitably modified to provide for such eventualities and incorporate provisions that avoid disputes.

2. Another issue is accepting the payments by contractor without any comment or accepting bill by client without any comment. It has been noticed that arbitrators have considered this acceptance as implicit acceptance of the terms in case a bill is accepted without any comment or information to contractor in case 
of rates being escalated by him. Similarly, receipt of payment by contractor on reduced rates and without a timely correspondence on record to show the disagreement has been upheld as implied agreement. Thus administrative procedures of both the parties are also responsible for such claims. Hence, such claims can be reduced by simply following robust processes of documentation and correspondence by both the parties.

\section{Recommendations for Category C6}

This category comprises claims that arise due to alleged recovery of materials and other deductions or rebates from contractor's bill. Since number of claims in this is the highest and also because the percentage amount awarded is moderately high and also because just like other categories, the claims arise and are awarded in favour of the contractor due to lack of proper evidences to support department's contention, it is imperative that efforts are made to reduce these claims to the maximum extent possible. Following are recommended approaches:

1. Contractor is supposed to use the material issued to him by the department in a reasonable manner. Client's representative should adequately notify the contractor for any misuse of material observed by him on the site (Written Communication).

2. Contractor while receiving the material issued to him by the department shall exercise thorough checks regarding quantity, conformance to specifications and other parameters regarding the material for any deviations from what is agreed as per the contract. Any deviation noticed by the contractor shall be reported in writing to the client (department) to avoid any disagreements while execution.

3. Also, the contract conditions must be explicit while defining the procedure and rates for determining any deductions that are to be made on account of over usage or under usage of supplied material. To avoid the issue altogether, issue of material may also be stopped altogether after carrying out cost benefit analysis which must take into account the cost of such disputes too.

\section{Recommendations for Category C7}

The claims under this category pertain to claims of extra work/items, substitutions/ deviations, etc. which arise due to differences in opinion about the rates of new items or rates of the items with changed specifications as well as Cost of works in dispute, which were not originally a part of the agreement between the two parties and were executed by the contractor as per client's/PM's instructions. The success rate for these claims is not very high. Nevertheless, it is imperative that these are addressed timely so that they never crop up.

1. The issue at the core always seems to be the method of arriving at the market rates of a particular item. Though sufficient changes have already been made to Clause 12 of GCC, it is advisable that a step by step method for calculation the revised rates is provided as a part of the clause so that contractor knows the procedure for arriving at the market rates in advance. 
2. Deviation in quantities can also be rendered immaterial by introducing rate contracts without specifying quantities. In such contracts, only rates of items are given and quantities are not mentioned and contractors quote rates on percentage basis on overall rates. Only gross amount of total work is mentioned and the terms and conditions of the contract specify that any item can or cannot be executed at site depending upon the site conditions. This way all the items in Delhi Schedule of Rates/Delhi Analysis of Rates (DSR/DAR) can be included in any contract and only those items can be executed which are required for that particular contract.

This will put to rest all the issues related to deviated items, extra items, change items, etc.

\section{Recommendations for Category M3 and M4}

These categories are related to claims that arise due to the parties resorting to arbitration i.e. the claims for arbitration expenses incurred by the parties and the recovery of loss of interest by the parties on amounts claimed due to delay in payment as the parties resorted to arbitration for resolution of disputes.

As a standard practice, the arbitration expenses are borne equally by both the parties, this could be agreed upon by the parties in the arbitration agreement itself to avoid waste of time and effort in resolving claims pertaining to these.

As regards the interests, the arbitration agreement may also incorporate rates of interests as mutually agreed and as normally awarded by the arbitrators in previous cases.

\section{CONCLUSION}

An objective of this paper was to determine if types of claims can be analysed in relation to contract conditions with an aim to affect claim prevention through proposed improvements in general conditions of contract. Twenty-two disputes in arbitration of public works, which are governed by GCC of CPWD were taken up for study and claims therein were studied and analysed. The study has shown that most of the claims have their genesis in contract conditions and by effecting changes in contract conditions, number of claims can be minimised to a large extent. To this end some recommendations have been proposed as changes in general conditions of contract that can help in minimising claims.

Dispute minimisation will always be an ongoing process because no matter how carefully a contract document is framed, the ever-changing circumstances in projects would always find a way of throwing newer issues. To be a step ahead of such issues, the concerned stakeholders must have the will for dispute avoidance rather than dispute minimisation. Once that is in place, the ways and means of dispute minimisation would find a way on their own.

The study has been carried out on a limited number of cases. Though, within these cases only, the nature of claims has been more or less consistent and hence may be assumed to be representative of a general trend. Notwithstanding this, the results must, however, be interpreted keeping this limitation in sight. 


\section{REFERENCES}

Assaf, S.A. and Al-Hejji, S. (2006). Causes of delay in large construction projects. International Journal of Project Management, 24(4): 349-357. https://doi.org/ 10.1016/j.ijproman.2005.11.010.

Brown, H. and Marriott, A. (1999). ADR Principles and Practice. London: Sweet and Maxwell.

Cheung, S.O. and Yiu, T.W. (2006). Are construction disputes inevitable? IEEE Transactions on Engineering Management, 53(3): 456-470. https://doi.org/ 10.1109/TEM.2006.877445.

Conlin, J., Lanford, D.A. and Kennedy, P. (1996). The Sources, Causes and Effects of Construction Disputes: A Research Project. London: Construction Industry Board.

Diekmann, J., Girard, M. and Abdul-Hadi, N. (1994). Disputes potential index: A study into the predictability of contract disputes. Construction Industry Institute Source Document 101. Texas: Construction Industry Institute.

Gupta, P., Gupta, R. and Netzer, T. (2009). Building India: Accelerating Infrastructure Projects. Mumbai: McKinsey and Company, Inc.

Heath, B., Hills, B. and Berry, M. (1994). The origin of conflict within the construction process. International Council for Research and Innovation in Building and Construction (CIB) Publication 171, Proceedings of First Plenary Meeting of TG-15. The Netherlands: CIB.

Hellard, R.B. (1987). Managing Construction Conflict. Harlow, UK: Longman Scientific Tech.

Hewitt, R. (1986). Winning Construction Disputes: Strategic Planning for Major Litigation. London: Arthur Young.

Indianconstructionindustry.com. (2007). Indian construction industry overview. Available at: http://www.indianconstructionindustry.com/overview.html.

lyer, K., Chaphalkar, N. and Joshi, G. (2008). Understanding time delay disputes in construction contracts. International Journal of Project Management, 26(2): 174-184. https://doi.org/10.1016/j.ijproman.2007.05.002.

Jones, S.R. (1994). How constructive is construction law? Construction Law Journal, 10(1): 28-38.

Kumaraswamy, M.M. (1997). Common categories and causes of construction claims. Construction Law Journal, 13(1): 21-34.

Mitkus, S. and Mitkus, T. (2014). Causes of conflicts in a construction industry: A communicational approach to contemporary issues in business management and education. Procedia: Social and Behavioral Sciences, 110: 777-786. https://doi.org/10.1016/j.sbspro.2013.12.922.

Mururu, N. (1991). Anatomy of a construction dispute. Arbitration, November: 262264.

Newey, J. (1992). The construction industry. In P. Fenn and R. Gameson (eds.), Construction Conflict Management and Resolution. London: E \& FN Spon, 20-23.

Odeh, A.M. and Battaineh, H.T. (2002). Causes of construction delays: Traditional contracts. International Journal of Project Management, 20(1): 67-73. https:// doi.org/10.1016/S0263-7863(00)00037-5.

Planning Commission, Government of India. (2008). Eleventh Five Year Plan 20072012. New Delhi: Oxford University Press. 
PricewaterhouseCoopers (PWC). (2014). Industrial and Infrastructure Construction in India. Kolkata, India: PwC.

Project Management Institute (PMI) (2017). A Guide to the Project Management Body of Knowledge (PMBOK Guide). 6th Ed. Newtown Square, PA: PMI.

Rephan, J. (2011). Arbitration of construction disputes. Pender and Coward, September.

Saurabh, S. (2001). Arbitration and Claim Management. New Delhi: Department of Building Engineering and Management, School of Planning and Architecture (SPA) Delhi.

Semple, C., Hartman, F.T. and Jergeas, G. (1994). Construction claims and disputes: Cause and cost/time overruns. Journal of Construction Engineering and Management, 120(4): 785-795. https://doi.org/10.1061/(ASCE)07339364(1994) 120:4(785).

Spittler, J.R. and Jentzen, G.H. (1992). Dispute resolution: Managing construction conflict with step negotiations. AACE International Transactions, 1: D.9.1-10.

Surawongsin, P. (2002). The implementation of construction claims management in the Thai construction industry. MEng diss. Asian Institute of Technology.

Sykes, J. (1996). Claims and disputes in construction. Construction Law Journal, 12(1): 3-13.

Tillet, G. (1991). Resolving Conflict: A Practical Approach. Sydney: Sydney University Press.

Watts, V.M. and Scrivener, J.C. (1993). Review of Australian building disputes settled by litigation. Building Research and Information, 21 (1): 59-63. https://doi.org/ 10.1080/09613219308727257.

Yates, D.J. (1998). Conflict and dispute in the development process: A transaction cost economic perspective. Available at: http://business2.unisa.edu.au/ prres/Proceedings/Proceedings 1998/Papers/.

Yates, J.K. and Epstein, A. (2006). Avoiding and minimizing construction delay claim disputes in relational contracting. Journal of Professional Issues in Engineering Education and Practice, 132(2): 168-179. https://doi.org/10.1061/(ASCE) 10523928(2006) 132:2(168). 